\title{
AFRICA AND INTERNATIONAL CORRUPTION: THE STRANGE CASE OF SOUTH AFRICA AND SEYCHELLES
}

\author{
STEPHEN ELLIS
}

THE SUBJECT OF CORRUPTION has emerged at the top of the agenda in recent dealings between African governments and the Western donors on whom many are heavily dependant. It is notoriously difficult to define corruption, ${ }^{1}$ but it is generally understood to entail the use of an official position for purposes of private enrichment or illegitimate advantage. During the 1970 s and 1980 s, there was a stream of books on corruption in Africa ${ }^{2}$ or on closely related concepts such as neo-patrimonialism, ${ }^{3}$ prebendalism ${ }^{4}$ and kleptocracy. ${ }^{5}$ Particularly since a World Bank report in 1989 explicitly spoke of a 'crisis of governance' in Africa south of the Sahara, ${ }^{6}$ much of the discussion of corruption south of the Sahara has been subsumed in a wider debate on governance.

The literature on corruption or on governance in Africa more generally tends to adopt a national perspective, investigating how national elites use corruption or manipulation of public policy to enrich themselves and maintain themselves in power. ${ }^{7}$ It is rather less frequent, at least in the academic literature, to encounter detailed studies of the relationship

Stephen Ellis is a researcher at the Afrika-studiecentrum, Leiden. He is grateful to Larry Gurwin for his comments on an earlier draft of this text and for extensive help with sources.

1. For some definitions, see Arnold J. Heidenheimer, Michael Johnston and Victor Levine (eds.), Political Comuption: a Handbook (Transaction Publishers, New Brunswick, 1989), pp. 3-68.

2. Robert Williams, Political Comuption in Africa (Gower, Aldershot, 1987). A useful periodical source is the journal Corruption and Reform, including a special number on Africa, 7, 3 (1992-3). On corruption and development, George Moody-Stuart, A Good Business Guide to Bribery: Grand comption in Third World development (Transparency International, Berlin, 1994).

3. Jean-François Médard, 'L'État patrimonial en Afrique noire', in Etats d'Afrique noire: formation, mécanismes et crise (Kathala, Paris, 1987), pp. 323-53.

4. Richard Joseph, Democracy and Prebendal Potitics in Nigeria: The rise and fall of the Second Republic (Cambridge University Press, Cambridge, 1987).

5. Stanislav Andreski, 'Kleptocracy as a System of Government in Africa', in Amold J. Heidenheimer (ed.), Political Corruption: readings in comparative analysis (Holt, Rinehart and Winston, New York, 1970), pp. 346-57.

6. World Bank, Sub-Saharan Africa: from crisis to sustainable growth (Washington DC, 1989), p. 60 .

7. Useful overviews of the literature on democtatization in Africa, including some studies of governance, are Rob Buijtenhuijs and Elly Rijnierse, Democratization in Sub-Saharan Africa, 1989-1992: an outview of the literarure (Research report 51, Afrika-studiecentrum, Leiden, 1993), and Rob Buijtenhuijs and Celine Thiriot, Democratisation in Sub-Saharan Africa, 1992-1995: an overview of the literature (Afriks-studiecentrum, Leiden, and Centre d'étude d'Afrique noire, Bordeaux, 1995). 
between corruption in various parts of Africa and that in industrialized countries. ${ }^{8}$

The present article is an attempt to trace the development of corruption in one part of Africa in a global context. It demonstrates how the ease with which capital can be transferred and commodities bought and sold and the speed of modern communication in general have been given considerable impetus to the linking of corrupt practices across borders, and that this process of trans-national corruption was considerably encouraged by the Cold War. The main focus of study is Seychelles, a small country but one which has the merit-if that is the right word-of providing interesting data on the subject under discussion. After independence in 1976 Seychelles was subject to intense international diplomatic and military activity, often of a covert nature, due largely to the islands' strategic location, which made them an asset both in US-Soviet rivalry in the Indian Ocean and in the more localized patterns of conflict stemming from South Africa's drive to assert its hegemony in southern Africa, notably by destabilizing or manipulating neighbouring states. This led to attempts to subvert or influence the islands' government by bribery and by force, while more powerful governments and business interests associated with political parties as far afield as Italy manipulated Seychelles' status as a sovereign state in order to perform various transactions of dubious legality. There is some evidence also that the islands were used for financial transactions by arms-dealers and as a staging-post for drugtrafficking. These various interests became intertwined with each other and with the Seychelles' government's own policies, having a demonstrable effect on governance in the islands.

It should be emphasized at the outset that not all the transactions, individuals or circumstances described here can be described as corrupt. On the contrary, one of the principal conclusions which can be drawn from the present essay is that grand corruption, sometimes masquerading as raison d'État, shapes the environment in which individual politicians, diplomats and business people are obliged to operate.

\section{Seychelles}

The Republic of Seychelles consists of over a hundred islands scattered over a wide area of the western Indian Ocean. Most of its population-a mere 60,000 people at independence in 1976, and less than 100,000

8. A non-governmental organization established in Germany in 1993, Transparency International, studies international aspects of corrption in the third world. German Foundation for International Development, Accountability and Transparency in International Economic Development: the launching of transparency intemarional (Zentralstelle für Wirtschafts- und Sozialentwicklung, Berlin, 1993). There is an abundant literature on illicit intemational business practices, money-laundering etc., in which Africa receives little attention since, in world terms, the African role in international business is small. See for example, Ingo Walter, Secret Money (Unwin, London, 2nd edn., 1989). 
today-is concentrated on just two islands. For a century and a half Seychelles was a remote and insignificant part of the British Empire. Only in 1971, as Britain renounced its colonial presence in the Indian Ocean, did the British government endow the islands with an international airport which was to transform their economic and strategic position by providing easy physical access to the rest of the world.

Britain's strategy for decolonization in the western Indian Ocean from the 1960s entailed divesting itself of colonies while detaching from the colonial administrative territories strategically useful islands which could become the sites for air and naval bases politically easier to manage than bases in more populous territories. ${ }^{9}$ As Seychelles became independent, Britain at first attempted to retain its influence by supplying the country's first president, Sir James Mancham, with covert political finance and security assistance. ${ }^{10}$ But Britain's political role in the region rapidly declined as Britain lost its ability to project its power world-wide. As the Indian Ocean emerged as a major site of Cold War strategic interest, ${ }^{11}$ it was the United States which tended to take over former British assets in the area. The US government built its principal air and naval base in the Indian Ocean a thousand miles to the east of Seychelles, on the island of Diego Garcia, a former dependency of Mauritius whose entire population the British government deported before leasing the island to the US. ${ }^{12}$ As part of its global military communications network the US government also built in the Seychelles an important satellite tracking station.

President Mancham was staunchly pro-Western in his foreign policy and seems to have envisaged attracting Middle Eastern petro-dollars for the economic development of his country, most notably through his highly public friendship with the Saudi businessman and arms dealer Adnan Kashoggi. ${ }^{13}$ But within one year of his election, on the night of 4-5 June 1977, President Mancham was overthrown in a coup by his prime minister, France Albert René. René's coup was aided by the government of Tanzania, and the new president soon took Seychelles into the left-wing camp in African politics. It became a one-party state. Nevertheless René continued his predecessor's policy of encouraging the creation of a tourist industry in the islands, and this has helped to make the country

9. Jean Houbert, 'The Indian Ocean Creole Islands: Geo-Politics and Decolonization', foumal of Madern African Studies, 30, 3 (1992), pp. 465-84.

10. Jonathan Bloch \& Patrick Fizzerald, British Intelligence and Cover Action (Brandon, Dingle, Co. Kerry, 1983), pp. 196-9. Cf. Mancham's own account in James Mancham, Paradise Raped (Methuen, London, 1983).

11. Philippe Leymarie, L'océan Indien: le noveau coeur du monde (Karthala, Paris, 1981).

12. Andre Oraison, 'Les avatars du BIOT (British Indian Ocean Territory). Le processus de l'implantation militaire américaine à Diego Garcia', Annuaire des pays de l'acéan Indien, vol. VI (Editions du CNRS, Paris, and Presses universitaires d'Aix-Marseilles, Aix-enProvence, 1979), pp. 177-209.

13. Christopher Lee, Seychelles: Political castaways (Elm Tree Books, London, 1976), pp. 1-3. 
today an economic success by African standards. President René, realising that Western holiday-makers were Seychelles' most obvious customers and source of foreign exchange, strove to maintain correct relations with Western governments as well as with the socialist countries where his personal political sympathies lay.

Much of the world's oil cargoes pass through the Indian Ocean, and in a period of turbulence in the Middle East and of Soviet ambitions to create a naval presence in the Indian Ocean, and especially after the 1979 revolution in Iran and the Soviet invasion of Afghanistan, the whole of the western Indian ocean rapidly increased in strategic importance. ${ }^{14}$ Seychelles was sufficiently important in Cold War strategic planning for the US government to be concerned by the pro-Soviet sympathies of the islands' government after the 1977 coup. France too had strategic ambitions in the Indian Ocean which caused it to take an interest in the islands; the government of Seychelles seems to have suspected the French government of being connected with a coup plot uncovered in the islands in 1979, expelling French military advisors and replacing them with Tanzanians and Algerians. ${ }^{15}$ The Soviet Union maintained a large embassy staff in Seychelles and for several years the Soviet ambassador was Mikhail Orlov, regarded by Western intelligence agencies as a senior KGB officer, said to have previously worked as the chief of the important KGB station in Turkey. Soviet warships paid courtesy calls to the islands and the Soviet Union also proffered other forms of assistance. Moreover by the early 1980s there were more than 100 North Korean military advisors in the islands. ${ }^{16}$ Another country interested in Seychelles was South Africa, whose government was concerned to prevent the Soviet Union from extending its influence in southern Africa, and which saw the Republic of Seychelles as a potential asset in South Africa's own ambition of securing regional hegemony.

Within a short time of its independence in 1976, then, Seychelles had become of considerable strategic interest to the two super-powers and to a number of lesser powers-France, South Africa and others-all of which sought to exercise influence in the islands. The country was exceptionally vulnerable to the pressures which larger governments could exert, largely because of its small size and tiny army, and perhaps also because its tourist industry was reliant on Seychelles' being able to maintain an image of tranquillity and unspoiled beauty in order to attract holiday-makers. One might add that the manner in which President René took power in 1977

14. Among several books on security in the Indian Ocean produced in the $1970 \mathrm{~s}$, see e.g. W. A. C. Adie, OI, Politics and Seapower: the Indian Ocean vortex (Crane, Russak, New York, 1975). On the later period, Leymarie, L'océan Indien.

15. Philip M. Allen, Security and Nationalism in the Indian Ocean (Westview Press, Boulder and London, 1987), p. 123.

16. 'An Indian Ocean Face-Off, Nezosweek, 17 September 1984. 
was a significant cause of instability, for, like most other coups, it had established a precedent for the transfer of power by unconstitutional means which was to put into question the government's legitimacy in years to come.

Beset by the attention of foreign secret services and by plots from within, President René turned for help to a friend, Giovanni Mario Ricci, an Italian businessman who had been living in Seychelles since shortly before independence. Due to the influence he had with René, Ricci was to become an important intermediary for foreigners wishing to cultivate commercial or political relations in Seychelles, as we will shortly describe in more detail. Mario Ricci was born near Lucca, Italy, in 1929. Convicted of fraud in Italy in 1958, he had gone to seek his fortune abroad. He was convicted a second time, in Switzerland, this time for possessing counterfeit currency. ${ }^{17}$ Ricci lived in Mexico and Haiti before making his way to Somalia where he set up a business exporting grapefruit. He was expelled from Somalia for reasons unknown around 1974, moving to settle in Seychelles. ${ }^{18} \mathrm{He}$ was a distinctive figure in the islands, instantly recognizable by his long beard, grown white since he first went to live in Seychelles.

Ricci became President René's friend and unofficial financial advisor. In 1978 he set up a company, the Seychelles Trust Company, in a joint venture with the Seychelles government. The government granted to the Seychelles Trust Company sole rights to incorporate off-shore companies and to act as resident agent for foreign companies and foundations registered in Seychelles, which could operate free of tax. The granting of this right to a private company was unique in that it made the Seychelles Trust Company the only private offshore business registration company in the world, and, in effect, Seychelles became the world's first socialist tax haven. ${ }^{19}$ In 1981 the government sold its shares in the Seychelles Trust Company, leaving Ricci in sole control. The cost of registering a foreign company, payable to the government, was a mere 1,500 rupees, or $\$ 300$.

It was to Ricci that President René turned for help after an attempted coup in 1981 (which is discussed in more detail below) had convinced him of the need to improve his government's security. At the President's request, Ricci hired private detectives to keep the exiled opposition under surveillance. ${ }^{20}$ - In 1982 a private detective employed by Ricci succeeded in planting a recording device in a London hotel room being used by

17. Affidavit dated 11 October 1986 submitted by G. Mario Ricci to the High Court of Justice of England and Wales, Queen's Bench Division, case of Giovanni Mario Ricci versus Paul Chow, 1986 R.No. 183: copy in the possession of the author. Also, François d'Aubert, $L$ 'argent sale: enquête sur un krach retentissant (Plon, Paris, 1993), pp. 155-65.

18. Gianfranco Turano, 'Promette il Paradiso', $l$ Mondo, 30 March-8 April 1991, pp. 75-9. 19. See Ricci's introduction to Claude Pavard, Seychelles, from one island to another (Editions Dellroisse, no place or date). Also Indian Ocean Nezusletter, 7 March 1992.

20. Interview with Mario Ricci in L'Espresso, 27 January 1985. 
Seychellois exiles to plot a coup against the government, and the tape was handed to the British press. ${ }^{21}$ Both the single party and the government of Seychelles came to rely on Ricci for various financial services, and accepted cash from him, in President René's words 'when [the government] needed to finance something for which we didn't immediately have the money'. ${ }^{22}$ Ricci in turn received privileged treatment from the government, and when one of his companies was nationalized, he was paid in cash, whereas other companies in a similar position received only government bonds. ${ }^{23}$ President René later stated that he had taken the precaution of asking the Italian authorities whether Ricci had a criminal record, but 'they told us that they had nothing on him.'24

Ricci was associated with some distinctly unusual companies in addition to the Seychelles Trust Company. In 1982 he was listed as a director of an entity immodestly entitled International Monetary Funding, or IMF, for short, not be confused with the International Monetary Fund. ${ }^{25}$ In 1984 he was accredited to Seychelles as a diplomat representing the Sovereign Order of the Coptic Catholic Knights of Malta which, it emerged, was a commercial company incorporated in New York. ${ }^{26}$ Seychelles was the only state in the world to recognize the order. ${ }^{27}$ President René later claimed that his government had granted Ricci diplomatic status in the mistaken belief that Ricci's Knights of Malta was in fact the Sovereign Order of Saint John, Knights of Malta, the well-known Vatican order of chivalry. Through his accreditation Ricci gained the right to use a diplomatic pouch and a diplomatic passport, and eventually he was to become the doyen of the diplomatic corps in the islands. President René also confided diplomatic missions to him, such as the improvement of relations with Somalia, where Ricci had once lived and where he still had useful contacts. ${ }^{28}$

Ricci increasingly used one of his many companies, GMR (named after his own initials), as a flagship for various interests. According to GMR's own company brochure it was 'a conglomerate of companies which operates throughout the world' and was 'managed from the operational headquarters in the Republic of Seychelles'. ${ }^{29}$ At various times GMR's

21. Barrie Penrose and Simon Freeman, 'The Plotters in Room 412', Sunday Times (London), 24 October 1982.

22. Interview with President Rent in The Indian Ocean Newsletter, 6 and 13 September 1986.

23. Seychelles Freedom Herald No. 7, September 1985, p. 3.

24. Interview with President René in The Indian Ocean Necosletter, 6 and 13 September 1986.

25. Michael Gillard, 'Banking Ripples from Seychelles', The Observer, 18 July 1982.

26. Martin Bailey, 'Unchivalrous World of the Bogus Knights', The Observer, 15 March 1987.

27. Indian Ocean Newsletter, 19 July 1992.

28. Giuseppe Meroni, 'La Victoria degli Italiani', Capital, August 1986, pp. 72-5.

29. 'GMR Group in South Africa', company brochure, no date. Also, 'G.M.R. Group alle Seychelles: Programma di Vendita di Azioni e di Obbligazioni Convertibili,' company brochure, May 1981. 
management, consisting mostly of Ricci and members of his and his wife's families, claimed to control companies in as many as 24 countries, including several in southern and eastern Africa as well as in more conventional business locations such as Britain and Switzerland, and tax havens including Panama, Liechtenstein and Luxembourg. This and Ricci's other companies in the islands were registered and run in conformity with Seychelles law. Already by the early 1980s, Ricci had acquired a reputation as someone who could be approached by anyone who wished to transact some form of business in Seychelles. Although having no official government position, he was diplomat, unofficial head of security, businessman and financial advisor to President René all rolled into one.

\section{South Africa}

Among the countries which had developed an interest in Seychelles was South Africa. At the time of the islands' independence in 1976, South Africa's National Party government was already feeling the impact of diplomatic isolation and of the gradual development of a military threat to its security. The government in Pretoria placed increasing importance on securing influence and the capacity to exercise force both within and outside its borders by clandestine means, notably through the development of its secret services (especially the Bureau of State Security, established in 1969) and the Department of Information. For as long as Namibia remained a South African colony, and Rhodesia, Mozambique and Angola remained under colonial or settler rule, South Africa itself was insulated from external aggression, but the situation changed rapidly with the independence of Angola and Mozambique in 1975 and the Soweto uprising of 1976.

The Department of Information was an agency of the South African government whose tasks included the covert distribution of government monies - in other words, bribery-to buy influence at home and abroad. This included in Seychelles. During Sir James Mancham's brief tenure of the presidency Seychelles was regularly visited by South African secret servants carrying '[bags full] of, bribe money to secure South African interests', the editor of the Johannesburg Sunday Express later recalled. ${ }^{30}$ In 1978 the Department of Information's role was exposed in a political scandal known as 'Muldergate' or 'Infogate', in which it was revealed that the Department had not only bribed journalists and secretly bought newspapers at home and abroad in a bid to secure better public relations, but that senior civil servants and politicians in South Africa had abused the Department's lack of parliamentary accountability for purposes

30. Obituary notice: 'Eschel Rhoodie', by Rex Gibson, The Independent, 28 July 1993 . See also Mancham, Paradise Raped. 
of personal enrichment-in other words, corruption. ${ }^{31}$ The Muldergate scandal became closely associated with the struggle to succeed the ailing Prime Minister, John Vorster, and to supplant the influence wielded by the Bureau of State Security (BOSS), which was headed by a political appointee, the prime minister's friend and confidant General H. J. van den Bergh. The favourite to succeed Vorster, Dr Connie Mulder, was disgraced as a result of the scandal and lost his claim to the premiership.

The person who emerged victorious from the political in-fighting surrounding the Muldergate scandal to become prime minister of South Africa in 1978 was the Defence Minister, P. W. Botha, who had powerful support from the generals of the South African Defence Force (SADF). The military men resented van den Bergh's and BOSS's pre-eminence in security manners and believed that the changed situation in southern Africa necessitated a complete overhaul of security policy under military direction. The security chiefs, the 'securocrats' as they came to be known, were to acquire great power under P. W. Botha's premiership and later presidency. They unveiled a comprehensive new strategy whose centrepiece was the defence of the South African state in the face of what the government saw as a comprehensive threat, a 'total onslaught' in Prime Minister Botha's words, orchestrated by the Soviet Union. ${ }^{32}$ Seychelles had a minor but distinct role in this strategy. The islands offered not only potential military facilities but also possible use as a base for clandestine trading purposes in the face of economic sanctions, especially after the Iranian revolution of 1979 had threatened South Africa's main supply of oil. South Africa in fact was to acquire most of its oil after 1979 from Saudi Arabia and the Gulf states. ${ }^{33}$

Due to a combination of the new defence strategy in Pretoria and the change in government in Seychelles in 1977, the South African secret services decided that bribery was no longer the most effective means of acquiring influence in the islands. In 1978 Seychellois exiles in South Africa, acting on behalf of ex-President Mancham, began discussions with officials concerning a coup attempt to be launched in Seychelles. The BOSS case officer who became most closely concerned with this scheme was one Martin Dolinchek. ${ }^{34}$ As plans for the Seychelles' coup developed the SADF lobbied to acquire control of the project, and the operation became the subject of an intense bureaucratic struggle between the military and the civilian intelligence service, The National Intelligence Service

31. Mervyn Rees and Chris Day, Muldergate (Macmillan South Africa, Johannesburg, 1980).

32. Joseph Hanlon, Beggar Your Neighbours: apartheid power in Southern Africa Oames Currey, London, 1986), pp. 7-16.

33. Shipping Research Bureau (R. Hengeveld \& J. Rodenburg, eds.), Embargo: apartheid's oil secrets revealed (Amsterdam University Press, Amsterdam, 1995).

34. Mike Hoare, The Seychelles Affair (Corgi edition, London, 1987), pp. 1-108. 
(NIS). The NIS was the direct descendant of the former BOSS, which had been disgraced in the Muldergate scandal and subsequently overhauled and twice renamed. Prime Minister Botha was more sympathetic to the military men than he was to the civilian intelligence service. In the end the government allocated planning for the Seychelles' coup operation to Military Intelligence, while the protests of the civilian intelligence service were mollified by the appointment of Martin Dolinchek as a liaison officer on behalf of the NIS. ${ }^{35}$ In order to provide a screen of deniability to the Seychelles' coup attempt the operation was entrusted to Mike Hoare, an Irish mercenary soldier who had made his name in the Congo but was now living in South Africa as a civilian. Hoare was later to testify that the coup plans were approved by the South African Cabinet and that weapons were provided by South African Military Intelligence. ${ }^{36}$ Most of the 45 or so people selected to carry out the coup were members of South African special forces, several of them former Rhodesian soldiers, some with earlier experience in the British army. ${ }^{37}$

On 25 November 1981 Hoare and his men landed at Seychelles international airport disguised as tourists, members of a drinking-club called the Ancient Order of Frothblowers. After a customs officer had found weapons in the luggage of one of the purported tourists, the invaders fought a brief gun-battle at the airport and escaped aboard an Air India jet which happened to be on the tarmac and which they hijacked. They left behind five soldiers, a female accomplice and also Dolinchek, the intelligence man. ${ }^{38}$ The Seychelles' government arrested and tried the six men, acquiring from them full information on the planning of the coup. Four of the six were sentenced to death. Hoare and some others were tried on their return to South Africa.

The Pretoria government, severely embarrassed, opened negotiations for the return of the six convicted mercenaries, and they were eventually returned to South Africa in mid-1983. The conditions for their release were not publicized, and only gradually did it become apparent that in the course of negotiations the South African government had not only paid to President René a ransom of $\$ 3$ million, ${ }^{39}$ but that this was part of a broader understanding with President René personally. His cabinet was not informed of the progress of the talks nor of the ransom payment. ${ }^{40}$ President René, alarmed by the succession of coup attempts against him,

35. Joseph Lelyveld, 'New Role for Pretoria Army Intelligence Unit?', International Herald Tribune, 11 May 1982.

36. Hoare, The Seychelles Affair, p. 77.

37. White Paper on Aggression of November 25th 1981 against the Republic of Seychelles (Department of Information, Victoria, Seychelles, 1982).

38. Two memoirs of the incident are Hoare, The Seychelles Affair, and Jerry Puren (with Brian Pottinger), Mercenary Commander (Galago, Alberton, South Africa, 1986).

39. The Independent, 29 July 1992.

40. Author's interview with former Foreign Minister Maxime Ferrari, Paris, 22 April 1993. 
asked Mario Ricci to help improve his security service. He realized that in order to survive he needed to adjust his foreign policy to accommodate South African interests, at least in some measure. The government also took a series of steps designed to mend fences with both South Africa and the US, whose own Central Intelligence Agency (CIA) had had foreknowledge of the coup attempt, ${ }^{41}$ and there was a notable shift in Seychelles' voting record in the United Nations and other international fora. ${ }^{42}$ The advent of a Socialist government in France in 1981 also helped to ease the pressure on the islands' government, since France maintained an interest in the region notably through its possession of the island of Réunion and military base in Djibouti. For its part, in 1983 the South African government uncovered a further coup plan which was under discussion and expelled from its territory Seychellois opposition activists including Gérard Hoarau, a former seminary student who had been detained in Seychelles in connection with the 1979 coup plot and had gone into exile. ${ }^{43}$ Hoarau was a cousin of René's wife and, speaking fluent Italian, had previously been a friend of Ricci.

It appears to have been in the aftermath of the 1981 coup attempt, during negotiations for the release of the six South African mercenaries, that the South African secret services first came fully to appreciate Ricci's significance as a potential intermediary with President René. At that time the number two person in section A, the foreign desk of the South African Security Police, was Craig Williamson, the country's best-known spy. Recruited by the Security Police while he was still at university in South Africa, Williamson had posed as a left-wing student activist and gone into exile, where he succeeded in infiltrating the ANC. In 1979 his true allegiance was revealed and he returned to Pretoria to take up a post at Security Police headquarters. To compound the damage inflicted on the ANC, he absconded from the organization with substantial funds in his possession. These he had turned over to the Security Police, and the ANC's money was later used to buy a farm near Pretoria which was to become a base for operations by Security Police death-squads. ${ }^{44}$ In 1985 Williamson resigned from the Security Police and publicly announced that he was going into business. It was not announced that he had at the same time been commissioned as a colonel in South African Military Intelligence. Williamson later explained his resignation from the Security

41. Lelyveld, 'New Role for Pretoria Army Intelligence Unit?'.

42. Arthur Gavshon, 'Seychelles Policies are Shifting to the West', The Star, 3 October 1983. This was confirmed by the author's own interviews with Seychellois officials.

43. 'Crackdown Seen as Part of Pik's New Diplomatic Drive', Star, 25 January 1984. Tony Stirling, 'Foiled Plot as "Double Agent"-Claim', The Citizen, 9 December 1983.

44. Jacques Pauw, In the Hean of the Whore (Southern Book Publishers, Halfway House, South Africa, 1991), pp. 59-60. 
Police on the grounds that 'I decided to get involved in proper intelligence work, especially on the international scene'. 45

By the mid-1980s Williamson and Ricci had developed a close relationship. In 1986, the year after Williamson's resignation from the police, Ricci's GMR company was registered to do business in South Africa and Williamson was appointed managing director of GMR South Africa and vice-president of GMR world-wide. In GMR's own company literature, the GMR conglomerate was henceforth said to be 'controlled from the executive offices based in Switzerland and South Africa.' The company prospectus represented GMR as a holding company which owned various companies world-wide. Some GMR subsidiary companies, it said, were local acquisitions made in the hope of being able to resell them again at a profit. Other subsidiaries it described as 'parked', dormant companies which could be activated to deal with specific transactions if necessary. ${ }^{46}$ Williamson assisted Ricci in acquiring permanent resident's status in South Africa. ${ }^{47} \mathrm{He}$ scoffed at pointed questions from journalists about Ricci's mysterious background, suggesting that any debatable points in Ricci's curriculum vitae could be explained quite easily. 'There is no hot money, or mafia money, in the GMR operation,' Williamson declared to the press. ${ }^{48}$ There is no evidence that Ricci was aware of Williamson's commission in Military Intelligence, but he must certainly have known of his earlier career in the Security Police.

The opening of GMR in South Africa, and the appointment of Craig Williamson as its managing director, gave Ricci access to business opportunities in South Africa, and by the same token it gave Williamson access to the GMR empire and to Ricci's business connections. Williamson hinted to journalists that his purpose was to use Seychelles and the GMR company to avoid the trade sanctions which were being applied with increasing severity to South Africa. 'I would like to assist South Africa in the economic warfare facing it', Williamson was quoted as saying, when asked about his new career as the chief executive of Ricci's GMR company. Williamson described GMR as 'flexible' and talked about how it could be used as a front by other companies seeking to do business with South Africa. 'If [GMR] is faced with anti-sanctions laws,' he said, 'it will restructure its activities to avoid any inhibiting laws.' 49 On another occasion Williamson divulged: 'we are involved in trade in strategic commodities. I don't want to go into details, but GMR has a background

45. Phillip van Niekerk, 'How We Bombed London', The Observer, 19 February 1995.

46. 'GMR Group in South Africa,' company brochure, no date.

47. Kitt Katzin, 'Ricci Expose: the Inside Story', Sunday Star, 7 February 1988.

48. Kitt Katzin, 'Nat Superspy's Shadowy Boss,' Sunday Star, 19 April 1987.

49. Sarah Sussens, 'Superspy Williamson Tums to Sanctions.' Sunday Tribune, 30 November 1986. 
in oil.'so In effect, although Ricci himself had virtually no experience in the oil business, he had earlier helped to introduce to Seychelles some Italians with extensive expertise in the oil business, to whom Williamson may have been referring. This will be discussed further below.

Williamson, cultivating his new persona as a trader, gave seminars to South African businessmen looking for new markets in the Far East and lectured on how to evade sanctions. ${ }^{51}$ He seemed intent on creating a political niche for himself as well, and his political ambitions clearly had support from the very top of the ruling party. In 1987 he stood for parliament as a candidate for the National Party in a suburb of Johannesburg but failed to secure election. Not to be thwarted, President Botha appointed Williamson a member of the President's Council.

By this time, South Africa's relationship with Seychelles was thoroughly ambiguous. Seychelles was often represented in the South African press, and the Western press generally, as pro-Soviet and anti-apartheid. In reality, Pretoria had developed closer relations with the government in Victoria in the months after the 1981 mercenary coup attempt and had expelled Seychellois opposition leaders from South Africa, but the South African secret services at the same time conspired with a group of coup-plotters based in Britain through a diplomat at the South African Embassy in London.52 The South African secret services eventually betrayed the coup plot to the Seychelles government in August 1986 and in effect aborted the plan. It seems that the South African strategy was to cultivate all sides in Seychelles with a view to cementing its own influence. After the August 1986 coup plot, South Africa's Military Intelligence had the Seychelles government under effective control, largely through Williamson and the relationship he had established with Ricci. GMR South Africa shared its Johannesburg office with another company controlled by Williamson, named Longreach, which acquired responsibility for government security in Seychelles after 1986. Years later, after the African National Congress had come to power, Williamson was to admit that Longreach was in fact secretly owned by Military Intelligence. ${ }^{53}$ Seychelles was all the more useful as a Military Intelligence asset because of its government's pro-Soviet reputation. In matters of strategic deception, the South African secret services had made considerable advances since the ham-fisted bribery of the Department of Information and the 1981 mercenary fiasco.

50. The Obsorver, 26 April 1987.

51. Byline Africa News Feature Service, 11/SO4/87.

52. Richard Dowden and Stephen Ellis, 'The Anatomy of a Conspiracy', The Independent, 23 October 1987.

53. Phillip van Niekerk, 'How Apartheid Conned the West', The Observer, 16 July 1995. See also Longreach registration records: Company file 86 02070/07, Registrar of Companies, Pretoria. 
Although Longreach purported to deal mainly in risk analysis, claiming officially to be advising businessmen on conditions for investment in southern Africa, particularly in Mozambique, Uganda and Burundi, 54 it in fact operated as an agent of Military Intelligence both inside and outside South Africa. Williamson once admitted that the company had engaged a French mercenary to carry out the attempted murder of President Lennox Sebe of Ciskei. ${ }^{55}$ This, it transpired, was part of an operation by South African Military Intelligence aimed at incorporating Ciskei into a larger new homeland. 56

South Africa's transition to democracy after 1990 did not mean the end of the covert networks established in earlier years, including those in Seychelles. Senior South African ministers continued to visit Seychelles: in April 1991 Defence Minister Magnus Malan visited the islands, following Foreign Minister Pik Botha who had also been on a visit earlier in the year. ${ }^{57}$ In 1994, the press reported that a South African naval officer, Commodore Willem 'Ters' Ehlers, who had succeeded Williamson as chief executive of GMR in South Africa, had negotiated with the Zairean government the purchase of some $\$ 40$ million of arms. These weapons were almost certainly intended for eventual transfer to Rwanda. Ehlers had worked as a private secretary to President P. W. Botha and it was in this capacity that he had first met Mario Ricci. ${ }^{58}$ After Botha's retirement, Ehlers had gone to work for GMR, apparently from 1990 until around 1992. A spokesman for GMR said in 1994 that both Williamson and Ehlers had ceased to work for the company.59 Williamson had indeed resigned on 31 December 1988 and Ricci in November 1991.60 A leading US human rights organization, Human Rights Watch, repeated the allegations the following year. ${ }^{61}$

This was one of several cases in the 1990s indicating the extent to which the South African state arms company ARMSCOR remained a major international arms dealer even after the end of the armed struggle for control of South Africa, both selling arms manufactured in South Africa and brokering

54. Author's interview with Major Michael Irwin, Longreach Managing Director, London, 24 July 1987.

55. Kitt Katzin, 'Superspy and the Jackal', Sunday Star, 28 February 1988; idem, 'Williamson Admits Tic to Mystery Mercenary,' Sunday Star, 6 March 1988.

56. Louise Flanagan, 'PW Knew of SADF Plan to Topple Sebe', Weekly Mail, 26 March to 1 April 1993. On the background, Jeff Peires, "The Implosion of Transkei and Ciskei', African Affair, 364, 91 (1992), pp. 365-87.

57. BBC Summary of World Broadcarts, 3 April 1991.

58. Sam Sole, 'Former PW Man in Rwanda Arms Link', Sunday Tribune, 3 July 1994.

59. Indian Ocean Nezasletter, 16 July 1994.

60. File number 86/02890/07, GMR Group South Africa (pty) Ltd., Registrar of Companies, Pretoria.

61. Human Rights Watch Arms Project, ReaandalZaire: Reaming with impunity (Vol. 7, no. 4, Washington and New York, May 1995). Stefaans Brümmer, 'SA's Arms-Dealing Underworld', Weekly Mail E Guardian, 2-8 June 1995. 
third-party deals..$^{62}$ In Africa today arms-dealing is a lucrative business, and also one with obvious political implications. Even since the demise of the National Party government in 1994 ARMSCOR continues to be something of a law unto itself, still largely staffed by the personnel of the apartheid era carrying out secretive weapons deals, some of which have embarrassed the ANC government, and making use of commercial networks created in earlier years in both public and private sectors. As with all modern weapons-deals, ARMSCOR's commercial sales have political implications. This is true of every country with a weapons-exporting industry. In the case of South Africa, however, the question is to know to what extent arms sales are under effective government control.

\section{Covert operations and corruption}

GMR and Longreach were only two of the hundreds of companies set up or acquired by the South African security establishment in pursuit of the strategy of counter-revolution. Some of these companies were used to trade in products subject to international sanctions, including oil, but also in less legitimate products such as ivory and rhino horn. ${ }^{63}$ One of Longreach's original board of directors, James Anthony White, a former member of the Rhodesian Selous Scouts, was reported to have an interest in the ivory trade. ${ }^{64}$ Front companies were used to channel weapons or supplies to South African allies in Angola, Mozambique and elsewhere. Some, like the network run by the main SADF death-squad, the Civil Co-operation Bureau, were used to carry out assassinations, and others for money-laundering or for peddling political influence. Another Military Intelligence front with which Williamson was associated, the International Freedom Foundation, succeeded in enlisting senior members of the Republican Party in the US, including Senator Jesse Helms, later to become chairman of the Senate Foreign Affairs Committee, in the campaign to defend apartheid. ${ }^{65}$

The securing of influence in Seychelles was very useful for various activities of this type. Thus, Chieftain Airlines, a front company used by the South African secret services which was later investigated for corruption, applied to the South African National Transportation Commission to fly Boeing $737 \mathrm{~s}$ between Johannesburg, the Comoros and Seychelles. ${ }^{60}$

62. A subject recently investigated by a judicial commission of inquiry in South Africa, the Cameron Commission.

63. Stephen Ellis, 'Of Elephants and Men: Politics and nature conservation in South Africa', Journal of Southern African Studies, 20, 1 (1994), pp. 53-70.

64. Environmental Investigation Agency, Under Fire: elephants in the front line (London, 1992), p. 35.

65. Van Niekerk, 'How Apartheid Conned the West'.

66. Kitt Katzin, 'The R 100-m Puzzle: Who is Backing Chieftain Airlines?, Sunday Star, undated clipping. On Chieftain Airlines, see Kommissie van Ondersoek na Sekere Moontike Oreëlmatighede, Hoofuerslag, Sy Edele Regter L.T.C. Harms (Staatsdrukker, Pretoria, 1989). Henceforth called the Harms Commission. 
The Comoros too were used by South Africa for clandestine arms shipments to the Middle East, and from 1979 South Africa paid the French mercenaries who were to run the islands' Presidential Guard until 1990.67

Pretoria's 'total strategy' required massive resources to implement and it required the people who managed it, the securocrats, to become interested in spheres of activity which are traditionally outside the scope of the military. Some of this was done openly; some of it required deception, either in the form of secret operations, or the establishment of secret organs of government, or the use of covert activity, meaning actions whose real purpose is other than the apparent one. The total strategy implied centralization of power and decision-making and a great expansion both of the role of the state and of the military and security branches within it. ${ }^{68}$ This had obvious political and constitutional implications for South Africa, and the increasing use of covert or clandestine operations in the service of the total strategy also had implications for the accountability of government and, hence, its tendency towards corruption.

Any sort of covert operation has numerous ramifications. If a military unit is secretly to channel arms to an ally, such as was actually done by the SADF in Angola and Mozambique, it must first procure the necessary weapons and ammunition. That means either manufacturing, capturing or purchasing them. Since the supply of these weapons is to be secret, the first option is not be recommended, as the weapons must not be traceable to the actual supplier if they fall into the wrong hands. It was far better for the SADF to capture Soviet-supplied weapons in Angola and then supply them to RENAMO in Mozambique, or even to buy them from Warsaw Pact countries on behalf of their clients, than to supply RENAMO and UNITA with standard SADF equipment. Whatever the source of the weapons, a covert armourer must establish a safe channel for their delivery, probably requiring aircraft and pilots, possibly ships, or at least trucks and drivers. Again, in the interests of secrecy, it is best not to use aircraft of the regular air force or army vehicles for this purpose, since that would make the operation too easy to trace back to the supplier government. Far better to use a front company, an airline or transport company which, like Chieftain Airlines or like the Frama company in Namibia, ${ }^{69}$ is apparently in the private sector, but is in reality controlled by the secret services. Pilots and truck-drivers are often men with families, and they require salaries,

67. Samantha Weinberg, Last of the Pirates: the search for Bob Denard Jonathan Cape, London, 1994), pp. 108-9. For background, see W. Andrew Terrill, 'The Comoro Islands in South African Regional Strategy', Africa Today, 33, 2-3 (1986), pp. 59-70.

68. Annette Seegers, 'South Africa's National Security Management System, 1972-90', foumal of Modem African Studies, 29, 2 (1991), pp. 253-73.

69. Ros Reeve and Stephen Ellis, 'An Insider's Account of the South African Security Forces' Role in the Ivory Trade', foumal of Contemponary African Studies, 13, 2 (1995), esp. pp. 231-3. 
insurance and pensions, which must also be arranged discreetly since the operatives are not officially on the government payroll but on that of a front company.

All of this means extra work for civil servants who must be employed for the purpose. It also requires money, which, to preserve confidentiality, can come from the secret budget of the state or from other sources. The latter are preferable since private-sector funding is less easy for hostile politicians, journalists and others to trace back to the government. The latter, in fact, is precisely what happened in the Muldergate affair, in that the funds used were relatively easy to trace and implicated politicians in decisions which they later found it impossible to deny with any degree of plausibility. Sometimes it is possible to 'launder' state funds destined for a clandestine operation so as to make them appear as if they emanate from the private business sector, or perhaps genuine businessmen can be induced to finance projects which are primarily of strategic interest. Again, these were all features of the financing of the Muldergate operation in the $1970 \mathrm{~s}^{70}$ Some front companies may actually generate commercial profits, which can be either diverted or ploughed back into the operation. If money is to be generated from clandestine trade or illicit business, it must be laundered or cleared through the banking system in such a way as to disguise its origin and destination, and this may involve breaking the banking laws, possibly of several countries. A pliable bank, or even a bank secretly controlled by the secret services, is an asset. Hence Chieftain Airlines was associated with a bank established in the Ciskei homeland which took unlicensed deposits and engaged in currency fraud. ${ }^{71}$ The bank's owner, a friend of Cabinet ministers Magnus Malan and Pik Botha, was in business with one Vito Palazzolo, an Italian who had worked as a money-launderer in the US and Europe for the important 'Pizza connection' mafia syndicate and had subsequently settled in South Africa. ${ }^{72}$

The difficulties inherent in money-laundering, it is relevant to note, are only one of several problems which secret servants intent on undertaking covert or clandestine operations share with drug-traffickers and other professional criminals. The creation of secret or covert networks, maintained with secret funds, inevitably attracts the attention of professional criminals and tempts otherwise honest people to steal, since the funds involved are publicly unaccountable. So it was in South Africa. Some companies set up by the secret services took illegal commissions or 'kickbacks' on otherwise legitimate contracts awarded by the

70. Rees and Day, Muldergate.

71. Harms Commission.

72. 'A Cute Little Bankhaus in Bisho', Noseweek, 9 (Sept, 1994), pp. 4-6. On Palazzolo, Ralph Blumenthal, Last Days of the Sicitians (Times Books, New York, 1988), esp. p. 316. 
government. This was particularly common in the South African homelands or bantustans, where there was little effective legal supervision of public works contracts and where corruption was rife. ${ }^{73}$ Other branches of the South African government used intermediaries to import oil, since South Africa's international isolation sometimes meant that a middleman had to be employed to disguise a transaction. This cost money in the form of the agent's commission and offered opportunities for official corruption. ${ }^{74}$

Front companies are commonly used by secret services operating in pursuit of state interests, and familiarity with their functioning is clearly part of the tradecraft of intelligence officers and specialists in low-intensity conflict. Politicians are necessary to any such operation, since their authority is needed to legitimize any covert operation, and in fact the element of political authority in such circumstances is crucial since it is political responsibility alone which constitutes the dividing line between a state-sponsored covert or clandestine operation and a purely criminal affair, carried out for private interest by professional criminals or by secret servants who have crossed the line to become rogue elements, disowned by politicians and liable to criminal prosecution. If a dishonest politician, whose authority is needed to provide top cover for an operation, demands a percentage of the financial transactions taking place within his or her sphere of interest, their demands can hardly be resisted. This was clearly the case in South Africa, as Dr Eschel Rhoodie, a senior official responsible for covert funding in the 1970 s, has testified. ${ }^{75}$

The recent history of South Africa shows clearly how the pursuit of state interests by covert or clandestine means, and the provision of funds or the implementation of plans which are not publicly accountable, encouraged the growth of corruption in South Africa and elsewhere. The system developed into a complex set of relationships in which secret services directly or indirectly developed commercial interests, and made increasing use of violence as well. In effect the secret services became associated with a spectrum of commercial and military or political activity. At one extreme were ventures such as the 1981 mercenary attack on Seychelles which were entirely military in nature. At the other end of the spectrum were legitimate commercial companies such as GMR. All of these had in common the presence of the South African secret services and, in particular, Military Intelligence. From the relatively straightforward bribery of the Department of Information there was a direct line of progression to the complex of commercial relationships in airlines, companies and legitimate

73. On the use of SADF front companies for political purposes in the homelands, Peires, 'The Implosion of Transkei and Ciskei'.

74. Shipping Research Bureau, Embargo, pp. 77-84.

75. 'Dr Rhoodie Talks about "South Africa's Biggest Secret"', Noseweek, July 1993, p. 5. 
or illegitimate trade in ivory and, according to at least one authoritative source, drugs. ${ }^{76}$

It was only after it had suffered severe embarrassment from the attempt to take over the government of Seychelles in 1981 that the South African secret services settled on subtler means. It was in this way, as the South Africans looked for ways of securing influence with President Renés government, that they came to appreciate the advantages offered by Mario Ricci's position in the islands and his contacts elsewhere.

\section{Political finance and corruption}

Others too were interested by Ricci's position in Seychelles. In 1980, a friend of Ricci's, the Roman banker Roberto Memmo, learned of Ricci's rights to incorporate offshore companies in the islands and established an offshore bank there, Roberto Memmo Investment Banking. ${ }^{77}$ Although it was not publicly known at that time, Memmo was a member of the Italian masonic lodge P-2, a secret organization of leading figures in Italian business, the security and intelligence services and politics, which, when its existence was revealed, caused a sensation in Italy. A parliamentary commission of inquiry in Italy established that the lodge had been closely connected with right-wing politics. In effect, during the 1970 s P -2 and the Italian secret services had conspired in a strategy aimed at preventing the election of a communist government in Italy, including by inspiring acts of right-wing terror such as the 1980 bombing of Bologna railway station. Leading members of $\mathrm{P}-2$ had also succeeded in infiltrating the finances of the Vatican. ${ }^{78}$

The full extent of corruption in Italian public life was to be fully laid bare only by the mani pulite ('Operation Clean Hands') investigations of the 1990s. At the heart of politics in Italy for several decades, it has now been proven, was a system whereby the main political parties received kickbacks in return for the awarding of public contracts from businesses and particularly from Italian parastatal companies over which politicians were able to exert influence. Secret networks like P-2 enabled obscure figures, such as the Venerable Master of the P-2 lodge Licio Gelli, to influence or even to blackmail politicians and government officials and also to negotiate with other important elements in Italian life, including the mafia and the Vatican. ${ }^{79}$ The illicit payments negotiated through such networks between businessmen and politicians were illegally transferred to the bank

76. Reeve and Ellis, 'An Insider's Account of the South African Security Forces' Role in the Ivory Trade', p. 232.

77. Gianfrancesco Turano, 'Quella Banca d'Altura', II Mondo, 30 March-8 April 1991; d'Aubert, L'argent sale, p. 162.

78. Martin Short, Inside the Brothertood (Grafton Books, London, 1990), pp. 160-2, $537-63$.

79. Alexander Stille, Excellent Cadavers: the Mafie and the death of the First Italian Repubbic Jonathan Cape, London, 1995), esp. pp. 11-12. 
accounts of various operators of the system and of individual politicians, usually through an elaborate series of transactions involving paper companies established for the purpose, and often by using offshore facilities in Switzerland, the Caribbean and elsewhere. The amounts of money involved were huge. One of the parastatal companies most deeply involved in this process was the Italian state oil company, the Ente Nazionale Idrocarburi (ENI), which was eventually found, as a result of the mani pulite judicial investigations, to have channelled over a billion and a half dollars to Italian political parties in illegal payments. ${ }^{80}$ As part of the political spoils system, Italy's leading political parties had also divided along geographical lines the political oversight of the large Italian development budget, with the Italian Socialist Party taking Somalia, for example, and another party, Mozambique. Each party thus took its cut of kickbacks from contracts given to Italian companies, as did the relevant officials and politicians in Africa itself. ${ }^{81}$ This system of political financing produced regular scandals in Italy whenever elements of the country's clandestine system of power-broking were made public. It was only in the early 1990s that circumstances permitted Italian judges to move against the political parties and influence-peddlers.

Among the most prominent scandals produced by this system was the 1982 collapse of the Banco Ambrosiano with unrecoverable loans of some $\$ 1.3$ billion, at that time one of the largest bank collapses in history, and the mysterious death of the Bank's chairman, Roberto Calvi, found hanging beneath London's Blackfriars Bridge. The bad loans had been made to shell companies actually controlled by Calvi and by the Vatican bank, the Institute of Religious Works. A considerable amount of the money, perhaps $\$ 250$ million, had been siphoned off by the Venerable Master of the P-2 masonic lodge. The Institute of Religious Works lost some $\$ 500$ million of Vatican money through its transactions with Banco Ambrosiano. ${ }^{82}$

A number of people closely associated with the Banco Ambrosiano, with ENI, and with the illicit provision of public funds to Italian political parties had dealings in Seychelles in the 1980s. Roberto Memmo, for example, worked as a commercial agent for ENI. ${ }^{83}$ A significant figure in Italy's political and financial underworld, Francesco Pazienza, arrived in Seychelles, on the run from the Italian police, in 1983. Pazienza was well-known in Italy, and his name had already been associated with several

80. Jan van der Putten, 'Italiaans Staatsoliebedrijf Kampioen Smeergeldbetaler,' De Volskrant, 18 February 1993.

81. Jean-François Médard, 'Les relations Nord-Sud: l'Afrique, les démocraties occidentales, et la corruption', Revue intemationale des sciences sociales (UNESCO, Paris, Sept, 1996), forthcoming.

82. Charles Raw, The Money-Changers (Harvill, London, 1992), p. 4.

83. Commissione Parlamentare d'Inchiesta sulla Loggia Massonica P2, Allegati Alla Relasione, serie II (Vol. I, Rome, 1984), pp. 586-92. 
major scandals. Pazienza had been a protégé of a chief of Italian military intelligence, General Giuseppe Santovito, who fell into disgrace when his membership of the P-2 masonic lodge became known, and Pazienza had been employed as a personal assistant by Roberto Calvi at a time when the Banco Ambrosiano chairman was desperately seeking financial support from the secret networks of Italian finance to cover the huge hole in his accounts. It was Pazienza who was in fact the originator of the Sovereign Order of the Coptic Catholic Knights of Malta, the company which Ricci was to represent as a diplomat in Seychelles, and it was from him that Ricci acquired the company.

Pazienza's extraordinary range of contacts in the fields of business, politics and intelligence extended to the US, where he had at one stage worked with a number of Americans associated with Ronald Reagan's 1980 election campaign. While Pazienza was an inveterate liar and fabricator of tall stories, it does appear that he had helped the Reagan campaign by supplying intelligence material calculated to embarrass Reagan's opponent, the incumbent President Jimmy Carter. ${ }^{84}$

When he arrived in Seychelles in 1983, Pazienza was wanted for questioning by the Italian police in connection with various affairs including the collapse of the Banco Ambrosiano. ${ }^{85}$ His ambitions were dazzling. He met Ricci and members of the government and shared with them his ideas for turning Seychelles into an entrepôt and operations centre for commodity transactions of various kinds, using the off-shore rights held by Ricci. He claimed to have the support of leading financiers in the US and elsewhere, and indeed many of those he named did not deny knowing Pazienza. Among the schemes which Pazienza claims to have conceived were plans to sell fishing-rights to Mexican interests and to use the islands as a base for dealing in cut-price Mexican oil. ${ }^{86}$ In November 1984 Pazienza learned from a government minister that two Italian policemen were on their way to Seychelles to arrest him and he hastily left the islands, travelling on a genuine Seychellois diplomatic passport. He was later arrested in the US and extradited to Italy. ${ }^{87}$

Following Memmo and Pazienza to Seychelles came another Italian connected to both ENI and the Banco Ambrosiano, the financier Florio Fiorini.8s Fiorini was the former finance director of ENI who had resigned after he was revealed to have prepared without proper authorization a scheme to use ENI funds in a bid to save the Banco Ambrosiano,

84. Jonathan Kwitny's stories on Pazienza in The Wall Street Joumal, 8 August 1985, and 9 August 1985. See also Larry Gurwin, The Calvi Affair (Pan, London, 1983), p. 191.

85. Raw, The Money-Changers, pp. 322-6.

86. Kwitny, The Wall Street foumal. See also the interview with Pazienza in Oggi, 5 June 1985; Seychelles Freedom Herald, August 1985. Supplemented by author's telephone interviews with Pazienza.

87. Kwitny, The Wall Street Youmal.

88. On Fiorini, see d'Aubert, L'argent sale, pp. 97-167. 
shortly before the Bank's collapse. ${ }^{89}$ During his career at ENI Fiorini had become a leading figure in the jungle of Italian political finance and had demonstrated a remarkable talent for financial manipulation. After leaving ENI he had gone on to build up a business empire on his own behalf. His main vehicle was a company called Société anonyme suisse d'exportations agricoles, known as SASEA.90 SASEA was an obscure Swiss agricultural products' company, part-owned by the Vatican, which had little to recommend it other than a listing on the Geneva stockexchange. Shortly after the collapse of the Banco Ambrosiano and his own departure from ENI, Fiorini assembled a consortium of businessmen, many of them previously associated with both ENI and the Banco Ambrosiano, ${ }^{91}$ who acquired and recapitalized SASEA. The company's chairman was no less than Nello Celio, a former president of Switzerland. In effect, Fiorini and his colleagues transformed SASEA into a merchant bank, buying, asset-stripping and selling companies and financing acquisitions in Europe and North America, while continuing to work closely with Italian politicians. Fiorini had especially close contacts with leaders of the Italian Socialist Party, especially Prime Minister Bettino Craxi and Foreign Minister Gianni De Michaelis, ${ }^{92}$ both of whom were to be convicted of corruption in 1995. (Their conviction is currently pending an appeal).

Fiorini visited Seychelles for the first time in 1983 or 1984 and met both Mario Ricci and President René.93 Fiorini had the idea of acquiring an oil-trading facility in Seychelles, and he and SASEA worked with President René to nationalize the Shell oil company in the islands. In 1985 the government nationalized Shell and replaced it with the Seychelles National Oil Company (SNOC), which also took a share-holding in a number of SNOC subsidiary companies. An Italian oil firm, a shareholder in SASEA with close associations with ENI, obtained a contract to manage the Seychelles' government's new oil interests. ${ }^{94}$ The government and Fiorini explained the nationalization by saying that it would enable Seychelles to sell fuel to aircraft and ships visiting the islands. Pazienza, by this time in detention, alleged that it was in fact the realization of his idea of using the islands to trade oil on the world market. 95

It was probably this development of Italian-run oil interests in Seychelles which prompted the South African Military Intelligence officer, Craig

89. Gurwin, The Calvi Affair, pp. 60-1, 131.

90. A good short description of SASEA is in two articles by Larry Gurwin \& M. Bakker, 'Waarom Hangt er zo'n Vieze Lucht rond Sasea?', FEM: Financied Economisch Magazine, 11-19 May 1990; and 'Italiaans Overname-Duo Botst met Beurzen', FEM, 20-28 May 1990.

91. D'Aubert, L'argent sale, p. 132.

92. D'Aubert, L'argent sale, pp. 123-51.

93. Florio Fiorini, Ricordái. ... da Lontano (Videopool, Milano, 1993), pp. 119-23.

94. D'Aubert, L'argent sale, pp. 152-5.

95. Seychelles Freedom Herald, August 1985. 
Williamson, to suggest in 1986 that he was joining GMR because of what he called its 'background in oil'.96 After Williamson's entry into GMR, there were rumours that the government of Seychelles and its parastatal oil companies were used as a cover for South Africa to import embargoed oil. This has never been proven, and oil traders and shippers did not report any extraordinary tanker movements to Seychelles. Nevertheless, a senior Seychellois diplomat has confirmed that, within a couple of years of Williamson's entry into GMR, Seychelles had come to occupy a place in South African sanctions-busting networks, apparently using paper transactions rather than physical transhipment of oil. ${ }^{97}$ It is noteworthy that Fiorini's former employer, ENI, developed such a system in the 1970s for selling Arab oil to Israel via front companies and paper transactions in the Bahamas, Malta and elsewhere. ${ }^{98}$ SASEA may also have entertained other ideas to make money from the boycotts imposed on South Africa. A private airline which inaugurated a weekly service from Nairobi via Mahé to Singapore, Ligne aérienne seychelloise, included at least one shareholder with close links to SASEA. It was planned to join this to a BotswanaSeychelles link. ${ }^{99}$

Among SASEA's acquisitions was a dummy company registered in Seychelles' offshore facility called the Seychelles International Bank, which Fiorini often called SIBANK and which appears to have developed from the earlier Roberto Memmo Investment Banking. The Seychelles International Bank did not have a full banking licence and, indeed, hardly had a physical existence. Fiorini transferred the bank's official headquarters to Switzerland, although such transactions as it carried out were actually performed from a small, shabby office in Monte Carlo. SASEA issued cheques on the bank in an effort to buy shares in an Italian insurance company. ${ }^{100}$

Fiorini went from strength to strength for as long as he enjoyed the patronage of leading Italian politicians. Through a series of companies, Fiorini, together with a partner, Giancarlo Parretti, who had only a few years earlier been convicted of fraudulent bankruptcy, ${ }^{101}$ eventually succeeded in a major business coup, acquiring the Hollywood film company MGM-United Artists for the sum of $\$ 1.3$ billion, after they had earlier been frustrated in an attempt to purchase the French film company Pathé. These acquisitions were made with massive loans from the Netherlands

96. The Observer, 26 April 1987.

97. Author's confidential interview, November 1988.

98. Larry Gurwin, personal communication.

99. 'Flying in the Face of Sanctions', Africa Analysis, October 1987. List of LAS shareholders in the author's possession.

100. D'Aubert, L'angent sale, pp. 151, 154.

101. On Parretti, Edward Jay Epstein, 'The Mystery of the Instant Mogul', Spy, June 1990, pp. 85-93. 
subsidiary of the French state-owned bank Crédit lyonnais. ${ }^{102}$ A French parliamentary commission of inquiry in 1994 failed to reveal any sound commercial reasons for the size of Crédit lyonnais' lending to such dubious financiers as Fiorini and Parretti. ${ }^{103}$ The commission's rapporteur, a deputy from a party opposed to the French Socialist Party which then held the French presidency, gradually put together a picture of political influence-peddling linking SASEA, Fiorini and Parretti with Socialist politicians in Paris, where Parretti had been the accredited representative of the Italian Socialist Party, Rome and even Spain. ${ }^{104}$ Using Crédit lyonnais Bank Nederland loans, the two Italians acquired a cinema chain in Britain and the Netherlands on behalf of the Italian media tycoon (and later prime minister) Silvio Berlusconi. ${ }^{105}$ They consistently managed to engineer major acquisitions not only with loans from Crédit lyonnais Bank Nederland, but also from their own Seychelles International Bank. For the MGM acquisition they also appear to have been supported by letters of credit issued by the Sovereign Order of the Coptic Catholic Knights of Malta. ${ }^{106}$ Seychelles International Bank was at the heart of Fiorini's and Parretti's finances. Where it acquired its funds from remains unclear.

SASEA was eventually to go bankrupt with debts of 2.7 billion Swiss francs, about $\$ 1$ billion. ${ }^{107}$ Tracing exactly what happened to this money will probably be no easier than it was in the case of the Banco Ambrosiano. Crédit lyonnais was left with ownership of MGM-United Artists, probably worth considerably less than what Fiorini and Parretti had paid for it, and with a loss of 6.9 billion French francs on its 1993 accounts, much of it stemming from the bad loans incurred by Crédit lyonnais Bank Nederland. ${ }^{108}$ It appears that Fiorini and Parretti, having learned their trade in Italian political finance and enjoying excellent relations with leading members of the Italian Socialist Party, had gone some considerable way to extending the Italian system of political financing to other countries, notably France, although this is a matter which requires further investigation.

\section{The US connection}

Some influential figures in the US, too, had formed an opinion of the ease with which the Seychelles' government could be swayed and of the influence enjoyed in the islands for some years by Mario Ricci.

102. Assemblée Nationale, Rapport de la commission d'enquête sur lo Crédit lyonnais (2 vols., Rapport no. 1480, Paris, 1994), I, pp. 71-86.

103. Assemblec Nationale, Rappon de la commission d'enquête sur le Crétit byonnais.

104. D'Aubert, L'argent sale.

105. Assemblee Nationale, Rappon de la commission d'enquête sur le Créctit lyonnais, I, p. 82.

106. D'Aubert, L'argent sale, pp. 416-8.

107. The Geopalitical Drug Dispatch, No 48 (October 1995), p. 8.

108. Assemblee Nationale, Rapport de la Commission d'enquête sur le Crédit byonnais, I, 23, $71-86$. 
US security and foreign policy in the early 1980s was a bone of contention not only between competing bureaucracies-at the White House, the State Department, the CIA and the National Security Council-but also a myriad of unofficial interests loosely attached to the political entourage of President Ronald Reagan and his Director of Central Intelligence, William Casey. This was the tangle which was to produce the Iran-contra affair, which came to public attention in 1986.

As CIA director from 1981 to 1987 , William Casey actively supported a network of unofficial contacts which, in his view, would assist in the ultimate aim of securing US security interests in the world. He enjoyed the unusual status for a Director of Central Intelligence of having cabinet rank and, in the opinion of some, he was to become the most important figure in the Reagan administration second only to the President himself. ${ }^{109}$ Casey was an old intelligence hand who had served in the Office of Strategic Services (OSS), the forerunner of the CIA, in the Second World War. A visceral anti-communist, he took up the post of CIA chief determined to restore America's capacity to fight its foes around the world which, in his opinion and that of many in the Republican Party and in the CIA itself, had been undermined by misguided efforts, particularly under President Jimmy Carter, a Democrat, to impose restrictions on the Agency. This, thought Casey, had had a disastrous effect on the CIA's effectiveness and morale. Casey and other Cold Warriors in the Reagan administration encouraged an array of informal contacts to build a private-sector network which could deliver help to America's friends and allies around the world without having recourse to what they considered the emasculated CIA or the fickle, Democrat-dominated, US Congress. The revelation of illicit deals with Iran and the Nicaraguan contras was eventually to expose the existence of other secret wars fought by Casey and the CIA extending to parts of the world other than Iran and Nicaragua, and arms-dealing links with South Africa. ${ }^{110}$ Casey's basic purpose was to get money and guns to any of America's allies who needed them in order that they might inflict damage on America's enemies, and principally the Soviet Union and its allies. The South African government clearly came into the Cold War category of friends of America. It was a bastion of antiCommunism in Africa and it was the main conduit to the UNITA organization in Angola.

Just as South African anti-communists saw the strategic possibilities offered by Seychelles, so did some in America. Some of Casey's associates, notably in the influential World Anti-Communist League, became

109. Joseph Persico, Casey: from the OSS to the CLA (Viking, New York, 1990), p. 575.

110. Contra Links Go Unnoticed,' Southscan, 15 October 1987; Bob Woodward, Veil: The secret wars of the CLA, 1981-1987 (Pocket Books, New York, 1987), p. 300; Steven Emerson, Secret Warriors: inside the coven military operations of the Reagan era (C. P. Putnam's Sons, New York, 1987), p. 222. 
interested in the islands, encouraging propaganda against its Socialistgovernment, depicted in a series of articles in the US and British press in the early and mid-1980s as a Soviet client, and fraternizing with the exiled opposition. In the wake of the 1983 US invasion of Grenada, it was not unrealistic to imagine the US government, or at least William Casey's fellow-travellers on the extreme right, backing a coup in strategically important, and allegedly Marxist-dominated, Seychelles. The US Department of Defense was concerned about the Seychelles' government's pro-Soviet tendencies and had its own connections to Defence Minister Ogilvy Berlouis, who was received at the Pentagon in 1985.111 It appeared that some in the US security establishment saw Berlouis as a potential future president of the islands, recognizing in him an ambitious man with no ideological baggage despite his tenure of a senior post in the René government. The coup plan aborted in August 1986 (described above) had the active support of the South African intelligence services and claimed support from prominent US anti-communists and from the British secret services.

Perhaps the greatest controversy surrounding the Iran-contra and associated networks was the precise role played by the two senior members of the US executive, President Ronald Reagan and Vice President George Bush. The latter was a former Director of Central Intelligence and, unlike Reagan, an expert in foreign policy. Both during the Reagan administration and during his own presidency, Bush had to fight to deny having had any role in the Iran-contra affair or in other affairs related to the US government's covert or semi-privatized diplomacy and secret wars.

In view of this, it is noteworthy that one of Bush's closest aides became associated with Mario Ricci in Seychelles. In February 1985, a partner in the US law firm used by Mario Ricci, former US Deputy Trade Secretary David R. Macdonald, travelled to Seychelles to discuss with Ricci and President René how the Seychelles government could best be represented in Washington. He then discussed the matter with Vice President Bush's press secretary, Peter Teeley. Teeley resigned his position at the White House on 1 March 1985 to open a public relations practice in the private sector. Within a week of his resignation Teeley had agreed to represent the government of Seychelles in Washington jointly with Macdonald, and the two of them undertook to introduce Seychellois ministers in Washington at whatever level they desired. ${ }^{112}$ The bill for these services, $\$ 6,000$ per month, was not paid by the Seychelles government but by Mario Ricci personally and correspondence concerning this lobbying

111. Author's confidential interview, Chicago, November 1988. See also correspondence between Peter Teeley and David Macdonald and Mario Ricci obtained from US Justice Department under the Foreign Agents' Registration Act.

112. David R. Macdonald to President René, 8 March 1985, obtained from US Justice Department. 
arrangement was addressed not to the Seychelles' government but to Ricci personally. ${ }^{113}$ In the circumstances, it is unlikely that Teeley would have resigned a senior position in the White House to take on this consultancy without informing his employer, Vice President Bush. It is testimony not only to the importance for the US government of developments in Seychelles at that time but also to the influence which Mario Ricci was acknowledged to have. It seems likely that senior US officials wished to cement their country's influence in Seychelles but also to outflank the more extreme anti-communists such as those of the World Anti-Communist League. ${ }^{114}$ Neither the South African government nor mainstream US agencies actually sought to overthrow President René by the mid-1980s, and certainly not after the failed coup of August 1986, since they already had him under control. They were probably most afraid, by this time, not that Seychelles was becoming a Soviet client but that it would be destabilized by extreme anti-communists working with William Casey. This threat from the extreme right was to disappear after exposure of the Iran-contra networks in America and after South Africa had aborted the 1986 coup. The ending of the Iran-Iraq war was later further to reduce the sensitivity of the western Indian Ocean.

American and South African interests in Seychelles were quite similar. The various arms of the US security establishment were generally agreed on the need to support the Pretoria government in the context of the Cold War, although it was not politically acceptable for Washington to state its support for the apartheid government in Pretoria unequivocally. There were also more complex aspects to this relationship. The US and South Africa were both on the same side in the Angolan war, and needed to cooperate in the supply of UNITA. In the Middle East, the US was determined to prevent an Iranian victory in the Iran-Iraq War and was supplying massive quantities of arms to Iraq but was also arming Iran in secret in order to secure the release of US hostages in Lebanon. Since the South African weapons industry was selling weapons to Iraq and being part-paid in Iraqi oil, ${ }^{115}$ the Americans had an interest in monitoring the flow of weapons from Pretoria to Baghdad so as to ensure the desired strategic balance between the two Middle Eastern rivals. At the same time Washington did not wish to disrupt Pretoria's oil supplies from Saudi Arabia and other Gulf states which supported Iraq in the Gulf War. As Indian Ocean islands, Seychelles and the Comoros stood in the middle of

113. Correspondence between Peter Teeley and David Macdonald and Mario Ricci obtained from US Justice Department. Supplemented by author's confidential interview, Chicago, November 1988.

114. On the WACL, Scott Anderson and Jon Lee Anderson, Inside the League (Dodd, Mead \& Co., New York, 1986).

115. Kenneth Timmerman, The Death Labby: how the West armed Iraq (Bantam, London, 1992), pp. 227-30. 
the sea-lanes and air-routes carrying weapons from South Africa to the Gulf and oil in the opposite direction.

\section{Some effects in Seychelles}

As bureaucrats and businessmen hammered out these strategic arrangements in offices in Washington, Geneva, Pretoria and elsewhere, and in business meetings in hotels all over the world, and as vast amounts of money changed hands, an atmosphere of intrigue and skulduggery settled on Seychelles and among some Seychellois exiles. There were occasional political assassinations or 'disappearances' in the islands, which although few in number, had an unsettling effect in such a small community. ${ }^{116}$ Gérard Hoarau, the most effective of the Seychellois exiles, published a series of detailed, well-documented and highly embarrassing allegations concerning corruption by the Seychelles government and promised further revelations ${ }^{117}$ which were never forthcoming: in November 1985, Hoarau was machine-gunned in a quiet London suburb. His killer, apparently a professional assassin, was never identified.

There were constant rumours that the islands were being used for heroin- and currency-trafficking. In late 1984, in the US, the New Jersey police found the mutilated bodies of two local drug-traffickers, apparent victims of a gangland killing. One of the two had in his pocket an address book which contained the name and address of Florio Fiorini and the name and private phone number of President France Albert René. The circumstances in which he had come to write these numbers in his address book were a mystery. The US ambassador to Seychelles at the time recalls that when he gave this information to the President, René went pale with apprehension. It was the only time that the ambassador recalls seeing René truly startled. ${ }^{118}$ Important international crime syndicates seem to have infiltrated much of the region: in London Francesco Di Carlo, a Sicilian convicted in 1987 of heroin-trafficking on behalf of a mafia crime family in a major trial, was shown to have regularly visited Mombasa, Kenya, where some casinos were said to be used by the Italian mafia for both money-making and money-laundering on a significant scale. ${ }^{119}$

Between the inception of Seychelles' private offshore tax haven in 1978 and 1992 some 40 companies registered to make use of the facility. ${ }^{120}$ According to Finance Minister James Michel, speaking in 1995, some of

116. Amnesty International, Seychelles: Political Imprisonment and Allegations Regarding the 'Disappearance' or Extrajudicial Execution of Suspected Opponents of the Govermment (AFR 50/02/85, London, 1985).

117. Notably in his newsletter, Seychelles Freedom Herald.

118. Author's phone interview with Ambassador David Fischer, February 1993. Also author's interview with Maxime Ferrari, Paris, 22 April 1993.

119. 'Mombasa Promises to Drive out the Mafia', The Times (London), 16 March 1987; 'Minister Warns Hotels on Mafia', Surday Times (Kenya), 29 March 1987. I am grateful to Martin Short for providing further background information on this case.

120. Indian Ocean Newsletter, 7 March 1992. 
them 'have been engaged in illegal activities and were being investigated by Interpol and the US State Department' ${ }^{121}$ In a court case in France in 1986, for example, it emerged that a company registered in the Seychelles' offshore facility had been used to transact major arms deals, possibly in an effort to acquire nuclear material for Libya. ${ }^{122}$

Finance Minister James Michel's acknowledgement in 1995 of the abuses of the Seychelles' tax haven and measures taken by him to reform the way in which the system worked do not signal an end to the islands' involvement in money-laundering. In November 1995, the Seychelles national assembly amended the constitution in order to open the way for legislation guaranteeing immunity from criminal prosecution for any foreign businessman investing a minimum of $\$ 10$ million in the islands. The Economic Development Bill provides immunity from prosecution for all investors meeting these requirements 'for all criminal proceedings whatsoever except criminal proceedings in respect of offences involving acts of violence and drug trafficking in Seychelles'. ${ }^{123}$ The director of Britain's Serious Fraud Office commented that it was 'the perfect present for drug barons, fraudsters and money launderers'. ${ }^{124}$

\section{The Cold War and global corruption}

The fact that South African secret servants, Italian businessmen and others were able to exert such pressure on the government of Seychelles, and indeed the influence which these people had in their countries of origin, should be considered in the context of the Cold War. It was the perception of a total onslaught against the government in Pretoria which led South Africa's politicians and secret services to adopt increasingly ruthless measures throughout the region and, as we have seen, these entailed a rapid escalation of corruption in South Africa itself. The same was broadly true of Italy, for the growth of corruption in Italian public life was directly connected to the fear in certain high circles of the Italian Communist Party coming to power in Rome. Organizations like P-2 were pledged to assure that this would not happen, and they were able to commit all manner of crimes, including massive corruption, in the name of anti-communism. For four decades Italian businessmen and voters and Italian politics itself were hostages to this system. ${ }^{125}$ It is no coincidence that the end of the Cold War was to encourage an extraordinary wave of political reform not only throughout Africa, including both Seychelles and South Africa, but also in Italy, where magistrates were at last able to indict politicians and others suspected of corruption.

121. Indian Ocean Newsletter, 14 January 1995.

122. Indian Ocean Necostetter, 7 March 1992; d'Aubert, L'argent sale, pp. 148-51.

123. Indian Ocean Netosletter, 18 November 1995.

124. Quoted in 'Revealed: Paradise for Crooks', Sunday Times (London), 14 January 1996.

125. Stille, Excellent Cadavers, pp. 9-10. 
Corruption on this scale, once entrenched, is hard to eliminate. A good example of this is provided by the maze of companies and organizations set up or acquired by the South African intelligence and security officers in their fight to defend apartheid. Front companies established by intelligence operatives are difficult to trace and difficult to close, not least since their existence may be quite legal and their formal ownership may be no longer vested in the state, but in nominees who cannot legally be dispossessed by administrative decree. Such companies are capable of transforming themselves, if necessary by acquiring a new name but continuing in the same business, as a snake sheds its skin. In this way the arrangements made in or concerning Seychelles in the 1970s and 1980s have produced a longer-lasting infrastructure of personal connections and institutions designed to evade national laws and to perform illicit transactions. There is evidence that illicit trade arrangements set up in southern Africa originally for military reasons survive in the form of networks engaged in the ivory, currency, diamond, drug and weapons trades. ${ }^{126}$ These trades have now become a major threat to the security of South Africa and they are an important feature of the political economy of various regions of Africa. This legacy is complicated by the fact that secret service and special forces operatives who have acquired expertise in covert operations have shown themselves capable of using their skills to mount totally independent ventures in the private sector. There are many examples of this, but an important one for the present discussion is the South African security company Executive Outcomes Ltd., which has worked in Angola, Sierra Leone and elsewhere and which has generated a wide array of front-companies in fields from air transport to video production. ${ }^{127}$ In a similar vein, successive companies manipulated or controlled by Italian political financiers have shown a similar tendency to resurface in new forms.

In general, the Cold War encouraged the development of relations between crime, politics and intelligence activity, largely because secret services and politicians who purported to be acting for the greater good of the West were prepared to tolerate or even to promote politicians of dubious morality and to do deals even with professional criminals, particularly in the Third World but also in the industrialized world. The longevity of the Italian mafia and the growth of the world narcotics trade are both in part consequences of bargains made by Western politicians and secret services with foreign governments or even with criminal elements in their own countries and sustained over considerable periods of time. ${ }^{128}$ The growth of transnational crime and of the corruption associated with it,

126. Ellis, 'Of Elephants and Men'.

127. 'Weapons for Sale', The Economist, 29 July 1995, and material published in the South African press concerning Executive Outcomes Lxd.

128. Stille, Excellent Cadavers, Alfred W. McCoy, The Politics of Herin: CLA complicity in the glabal drug trade (Lawrence Hill, New York, 1991). 
often seen nowadays as an emerging security threat to the nations of the West, grows out of the Cold War itself.

If a government or an individual politician in an African country is offered unaccountable funds by foreign governments, and is made to understand that refusal can entail violent attempts to overthrow the government, it becomes more understandable why some politicians may come to see international politics as a jungle, in which richer governments ruthlessly pursue their perceived national or factional interest at the expense of smaller and poorer ones. Not all African governments are subject to the same pressures as those applied to Seychelles, but there are certainly many blandishments and threats which are never publicly reported and are not assimilated in academic analyses of corruption and governance. In the case of Seychelles, and no doubt in many other cases also, many of the pressures or promises offered from abroad were articulated by various secret services. While there is an enormous literature and an array of specialist journals on secret services, academic studies of intelligence and security services have devoted little attention to Africa in general, with the partial exception of South Africa. ${ }^{129}$ The evidence of the present study suggests that intelligence services play an important role not only in the politics of some African states but also in relations between rich countries and Africa and that, not surprisingly, they are often charged with the more delicate or less acceptable tasks of diplomacy. If the case of Seychelles is anything to go by, intelligence services in developed countries are largely concerned with carrying out aspects of foreign policy which are to be concealed from the domestic public rather than any other function.

If this observation is correct, the inferences which follow apply at least as much to the wealthier nations of the world as to African governments. And if analysis of the activities of major intelligence agencies in Africa tells us something about the nature of governance in some of the world's older and wealthier democracies, it also tells us something about the nature of the political enterprise in those same democracies. Much of the unorthodox or illicit financial activity in Seychelles directly or indirectly was connected with the funding of political parties or individual politicians. This was so not only in the case of funds used for Seychelles' own ruling party, but also in regard to Italy. SASEA's extraordinary relationship with Crédit lyonnais suggests the existence of a particular relationship with Italian political parties and perhaps also with the French Socialist Party. Political parties in modern advanced democracies, it seems, are permanently in search of funds in excess of what they can obtain from domestic party members

129. Roy Pateman, 'Intelligence Agencies in Africa-a Preliminary Assessment', fournal of Modern African Studies, 30, 4 (1992), pp. 569-85. On South Africa, Robert d'A. Henderson, 'South African Intelligence under de Klerk', Intemational foumal of Intelligence and Counter Intelligence, 8, 1 (1995), pp. 51-89. 
of sympathizers. The competition for political power is such that they may be prepared to seek such funds from unorthodox or illicit arrangements with business, or with their own secret services, or a combination of the two. Money can be laundered in real-estate transactions and leveraged buy-outs of the type undertaken by SASEA, in which political support is crucial. It can also be laundered in some circumstances through the media industry, and here the attempts of Florio Fiorini and Giancarlo Parretti to buy film companies and newspapers meshed with the interests of politicians in acquiring influence with the media. Media magnates-cum-politicians such as Silvio Berlusconi are products of this tendency.

Inasmuch as Africa is a field where the governments of powerful countries can pursue factional or personal interests virtually unchecked, Africa may be a more significant factor in the politics of some Western countries than is generally imagined, due to the relative ease with which unaccountable funds can be obtained or laundered there. ${ }^{130}$ The globalization of capital movements makes it all the easier and more tempting to carry out such transactions abroad, and here small and easily manipulable states like Seychelles are an obvious attraction. Political job-men and money-launderers come into contact with professional drug-smugglers, and streams of business, political and criminal finance may merge. Africa's role in the international narcotics trade, we may note, is increasing rapidly, not as a producer but as an intermediary for products consumed in North America and Europe. ${ }^{131}$

In this way problems of political funding, crime and governance more generally in the rich world become inseparable from related problems in Africa itself. The networks thus established may become independent of their political instigators, creating power blocs with enduring interests which survive changes of regime in, for example, Rome, Paris or Pretoria. The impression gained by the French Member of Parliament François d'Aubert, chairman of the Anti-Mafia Commission of the French National Assembly and rapporteur of the Commission of Inquiry into Crédit lyonnais, is worth citing as a description of the nebulous political-financial networks in modern democracies: ${ }^{132}$

I observed a shadow area, a zone of contact between legality and illegality, between the licit and the criminal, between clean money and dirty money, between honest people and out-and-out crooks. It is a no-man's-land dominated by a demi-monde of intermediaries of every kind, of corrupters and corrupted enjoying complete impunity for laundering money in investments which are clean, safe and profitable.

130. Stephen Smith and Antoine Glaser, Ces Messieurs Afrique (Calmann Levy, Paris, 1992). 131. United States Department of State, Bureau for International Narcotics and Law Enforcement Affairs, International Narcotics Control Strategy Report (Washington DC, March 1995).

132. D'Aubert, L'argent sale, p. 545. 
In South Africa, the growth of political corruption was associated with a very special factor, namely the protracted struggle to defend apartheid. South Africa and southern Africa may feel the effects of methods used in the service of the total strategy for years to come as Pretoria's former secret servants continue their careers either inside or outside the public service. Trans-border trafficking of drugs and weapons is frequently seen by commentators, and by the South African government itself, as a major security threat in an age, and in a part of the world, where conventional wars between states seem to have become obsolete and to have been replaced by armed conflict carried out by factional interests, often associated with international trades in illicit products, including narcotics. Funds gained from enterprises of this type can be channelled into political finances, and in South Africa, as in Italy and elsewhere, the dividing lines between secret services, organized crime and political parties may be seen to have become blurred to a considerable degree.

In much of tropical Africa, the decline of state power in recent years has resulted in the emergence of networks of long-distance trade in high-value commodities including gems, weapons and drugs which are both sources of wealth and vectors of political-military conflict, such as in Liberia, Angola, Somalia and elsewhere. ${ }^{133}$ This is an important development in which anti-corruption or good governance campaigns are of little relevance, since either these trades are outside the control of collapsed states, or the political powers which are emerging depend on them for their own finances. Such long-distance trades are producing new patterns of politics in Africa in which secret services or privatized security organizations like Executive Outcomes are playing an important role. There are examples of major banks which launder drug-money and facilitate more traditional forms of corruption such as bribery and capital flight for governments and for individual clients but which are also tolerated by major Western intelligence agencies which find it convenient to observe, but not to denounce, the illicit flows of financing for states, drug barons, political parties and terrorist organizations. BCCI, the Bank of Credit and Commerce International, whose collapse marked the biggest bank failure in history, is the best-known example. ${ }^{134}$ The detailed reconstruction in the present article may serve as a contribution to a deeper understanding of the origins and nature of these contemporary phenomena which are inextricably associated with general questions of governance and politics.

133. The Centre d'études des recherches internationales, Paris, represented by JeanFrançois Bayart and Béatrice Hibou, and the Afrika-studiecentrum, Leiden, represented by myself, are currently carrying out a project on the Criminalization of the State in Africa.

134. Peter Truell and Larry Gurwin, False Profits: the inside story of BCCI, the coorld's most comspt financial empire (Houghton Miffin, New York, 1992). 